DOI https://doi.org/10.18551/rjoas.2017-10.05

\title{
MANAGEMENT OF SCHEDULING OPTIMIZATION OF SUPPORTING FACILITIES AND INFRASTRUCTURE DEVELOPMENT PROJECT IN THE AREA OF FOLDER AIR HITAM SAMARINDA
}

\author{
Hermawan Achmad Febrian*, Mulyadi Lalu, Putranto Edi Hargono Dwi \\ Civil Engineering Department, Construction Management Concentration, National Institute of \\ Technology, Malang, Indonesia \\ *E-mail: achmad.febrian199@gmail.com
}

\begin{abstract}
Supporting Facilities and Infrastructures Development Project of Folder Air Hitam Samarinda is realized by PT. Trinanda Karya Utama. This project has a possibility of retardation, so it results to the retardation of other activities. One of the ways to anticipate it by conducting acceleration which is by Time Cost Trade Off (TCTO) method through alternative of adding working hours in the trial ranging from 1 hour to 4 hours at maximum limit. It aims to analyze the time and cost needed by the implementation of TCTO in completing the development of Supporting Facilities and Infrastructure of Folder Air Hitam Samarinda. In realizing the design of the acceleration, it is started from the network creation of Critical Path Method (CPM) to know the existence of critical path, then TCTO method is applied to find the cost slope value of each of these critical activities. In order to realize the acceleration, then compression is done further on critical work items starting from the value of the lowest cost slope. The results of this study show that for overtime work of several activities ranging from overtime 1 hour to 4 hours, time and cost obtained over 2 hours overtime on mini pile work, poor plat sand backfill, sills + windows J3, ceiling paint, PVC toilet wall with 86 days, the cost needed is $4.532 .921 .979,82$ and the additional cost is IDR $371.312 .000,00$.
\end{abstract}

\section{KEY WORDS}

Crashing, financing, scheduling, time cost trade off.

Along with the development of the industrial world as well as the development of transportation facilities, especially roads that are growing rapidly, the difficulty level to manage and run a road project is also higher. The higher the difficulty level, the longer the duration of time needed to complete the project.

Project generally has a certain time limit in the matter of supporting facilities and infrastructure in the area of Folder Air Hitam Samarinda. Project is subjected to re-scheduling because of there is a retardation of materials, and it does not meet initial project planning. There are many factors causing retardation in project implementation, internally the retardation in project implementation is caused by: the use of labor that does not match the target productivity, the lack number of personnel, improper implementation method, etc.; while externally the retardation is caused by equipment or materials, weather, etc.

\section{METHODS OF RESEARCH}

The obtained data are then analyzed by using Critical Path Method (CPM) and Time Cost Trade Off (TCTO), (Yamin and Harmelink, 2001). The steps in data processing are as follows: for scheduling purposes, some relatively similar activities are grouped; determining the order of work of the planned activities; making a network diagram; estimate the time taken for each activity; determining critical path; determine the value of additional cost (cost slope); method compression of Time Cost Trade Off; Illustrate the graph of time and cost relationship; determine optimal time and cost.

Grouping of Project Sections. In the Supporting Facilities and Infrastructure Development Project in the area of Folder Air Hitam Samarinda, it consists of four main works. Each section is composed of more specific work items. In the project, scheduling 
used is time schedule (S curve). This project is scheduled for completion in 100 calendar days, starting from September 10, 2014 to December 18, 2014.

Where the additional cost of acceleration is expected later will be more effective than the cost of retardation that must be spent. To conduct an acceleration analysis of time, then the existing job description will be rescheduled by using network planning Critical Path Method (CPM).

Total Cost Normal. In the Supporting Facilities and Infrastructure Development Project in the area of Folder Air Hitam Samarinda, the contract value is IDR 4.152.506.000,00.

Indirect Costs. Indirect costs are costs that are not directly related to construction, but it must exist and it cannot be separated from the project. The indirect costs include overhead costs, profit, unexpected costs, and value added tax (VAT) which are explained as follows.

Overhead. Overhead costs are the wages of project staff and the cost of field facilities. The overhead costs identified in the Supporting Facilities and Infrastructure Development Project in the area of Folder Air Hitam Samarinda are IDR 890.000,00. With salary for each staff is project manager IDR 170.000,00; site manager IDR 100.000; surveyor IDR 100.000; drafter IDR 85.000; quality control IDR 100.000; site engineer IDR 100.000; administration staff IDR 85.000; and daily cost IDR 150.000. The staff directly involved in overtime work at the project site are field managers and quality supervisors. Field managers and quality supervisors are then reported to the site manager to be able to carry out activities that will have overtime work. Details of overtime costs incurred for staff in the field are as follows.

Total staff salary per day $=$ Salary field manager + quality controller $=$ IDR $200.000,00$

Total staff salary per hourly $=\frac{\text { Total of Daily Wage }}{\text { Normal } \text { Working Hour }}=\frac{R p 200.000,00}{7 \text { Hours }}=$ IDR 28.571,43

Profit. Contractors' profit is the profit earned on a project that has a difference between the Budget Plan (RAB) and the Implementation Budget Plan (RAP). Profit here is divided into two kinds, namely gross profit and net profit. The gross profit is the profit earned by $10 \%$ of the real cost, which includes the overhead cost incurred by the contractor. Real cost for this project is IDR 3.775.006.345,29 with real cost for each sub task are first floor breakdown IDR 1.647.987.848,32; second floor breakdown IDR 1.263.701.785,97; landscape and structure IDR 863.316.711,00.

Unexpected costs. Under the contractual agreement, the unexpected cost is $2 \%$ of the real cost.

Value Added Tax (VAT). Based on the letter of contract agreement, the cost of Value Added Tax (VAT) is $10 \%$ of the real cost incurred by the contractor.

The full details of indirect costs of Supporting Facilities and Infrastructure Development Project in the area of Folder Air Hitam Samarinda detail of indirect cost for 100 days project as mentioned above consists of overhead cost IDR 364.900.000,00; daily cost IDR 890.000,00; profit IDR 288.500.634,53; unexpected cost IDR 75.500.126,00; with daily cost consumption IDR 755.001,27 and valued added tax IDR 377.500.634,53.

Implementation of Time Cost Trade Off Method. Implementation of TCTO method it can be made when acceleration work duration in critical path. Project is executed at normal working time with 1 hour to 4 hour maximum experiment time. Step for implementing TCTO method is as follows.

Normal Duration (ND). Normal duration is the time needed to complete the job until it is done normally. Normal duration can be known in the S curve scheduling.

Normal Cost (NC). Normal Cost is the cost needed to complete the work with the normal time period. The stages are as follows:

Determining the unit price of workers' wages. Workers' wages earned from data PT Trinanda Karya Utama with value of foreman IDR 125.000,00; head laborer IDR 100.000,00; high skilled laborer IDR 90.000,00; laborer IDR 70.000.

Determination of Critical Path. In the CPM method, there are two estimation of time and cost for each activity in the network. Both estimations are the estimated time of completion 
and the normal cost (normal estimate) and the estimated time of completion and the cost of which is crash estimate. In determining the approximate time of completion, the term of critical path will be known which is the path that has a series of activities with the longest total amount of time and the fastest project completion time. In the calculation time, three basic assumptions are also used: First, the project has only one initial event (start) and one terminal event (finish). Secondly, the fastest event of the initial event is the zero day. Third, the slowest occurrence of the event terminal is LS = ES.

If both calculations have been completed, then Slack or Float value which is a number of leeway time and elasticity in a network work can be obtained. Meanwhile, there are two kinds of Slack namely Total Slack and Free Slack.

Optimization Analysis. After going through several stages in the implementation of TCTO methods to analyze time and cost, identifying critical paths on CPM network planning is firstly started. Then, project financing is identified. Afterwards, TCTO method to find the cost slope value of each critical job is implemented, and the compression for each critical job is done, all of which are aimed at getting the targeted time and cost.

The following table shows some activities that can have overtime work for each overtime hours on Supporting Facilities and Infrastructure Development Project in the area of Folder Air Hitam Samarinda.

Table 1 - Activity that Has Overtime Work

\begin{tabular}{|c|c|c|c|c|c|c|c|c|c|c|}
\hline \multirow{2}{*}{ No } & \multirow{2}{*}{ Kegiatan Yang Dilemburkan } & \multirow{2}{*}{ Normal Duration } & \multicolumn{3}{|c|}{ Crash Duration } & \multicolumn{3}{c|}{ Total Crash } \\
\cline { 4 - 10 } & & & I & II & III & IV & I & II & III & IV \\
\hline 1 & Papan Nama Proyek & 2,89 & 2,56 & 2,35 & 2,22 & 2,15 & 0,33 & 0,54 & 0,67 & 0,74 \\
\hline 2 & Pancang Mini Pile & 21,00 & 18,61 & 17,09 & 16,15 & 15,64 & 2,39 & 3,91 & 4,85 & 5,36 \\
\hline 3 & Urugan Pasir Bawah Poor Plat & 10,92 & 9,68 & 8,89 & 8,40 & 8,13 & 1,24 & 2,03 & 2,52 & 2,79 \\
\hline 4 & Kusen + Pintu Type P1 & 12,11 & 10,73 & 9,86 & 9,32 & 9,02 & 1,38 & 2,25 & 2,80 & 3,09 \\
\hline 5 & Cat Plafond & 13,30 & 11,78 & 10,82 & 10,23 & 9,90 & 1,52 & 2,47 & 3,07 & 3,40 \\
\hline 6 & Railing Pagar Hollow Steinless & 14,00 & 12,41 & 11,40 & 10,77 & 10,43 & 1,59 & 2,60 & 3,23 & 3,57 \\
\hline \multicolumn{3}{|c|}{ Jumlah Total Crash } & & 8,46 & 13,81 & 17,13 & 18,95 \\
\hline \multicolumn{3}{|c|}{ Total Waktu Normal Waktu Proyek Setelah Dilemburkan } & 100 & 100 & 100 & 100 \\
\hline
\end{tabular}

Based on the above tables, it can be obtained recapitulation of time and cost of the activities having overtime work in each overtime hours. The fastest time recapitulation with new project costs and additional costs can be shown in the following table.

Table 2 - The Fastest Time Output with Total Cost of TCTO

\begin{tabular}{|c|c|c|c|c|}
\hline Overtime & Duration & Direct Cost & Indirect Cost & Total Cost \\
\hline Normal & 100 & IDR $3.396 .750 .709,50$ & IDR $830.501 .395,96$ & IDR 4.152.507.000,00 \\
\hline 1 Hour & 91,54 & IDR $3.398 .159 .770,69$ & IDR $819.409 .714,36$ & IDR 4.217.569.000,00 \\
\hline 2 Hours & 86,19 & IDR $3.400 .849 .548,35$ & IDR $813.826 .343,80$ & IDR 4.214.676.000,00 \\
\hline 3 Hours & 82,87 & IDR $3.403 .682 .464,74$ & IDR $811.296 .327,14$ & IDR $4.214 .979 .000,00$ \\
\hline 4 Hours & 81,05 & IDR $3.406 .816 .503,02$ & IDR $811.170 .936,62$ & IDR $4.217 .987 .000,00$ \\
\hline
\end{tabular}

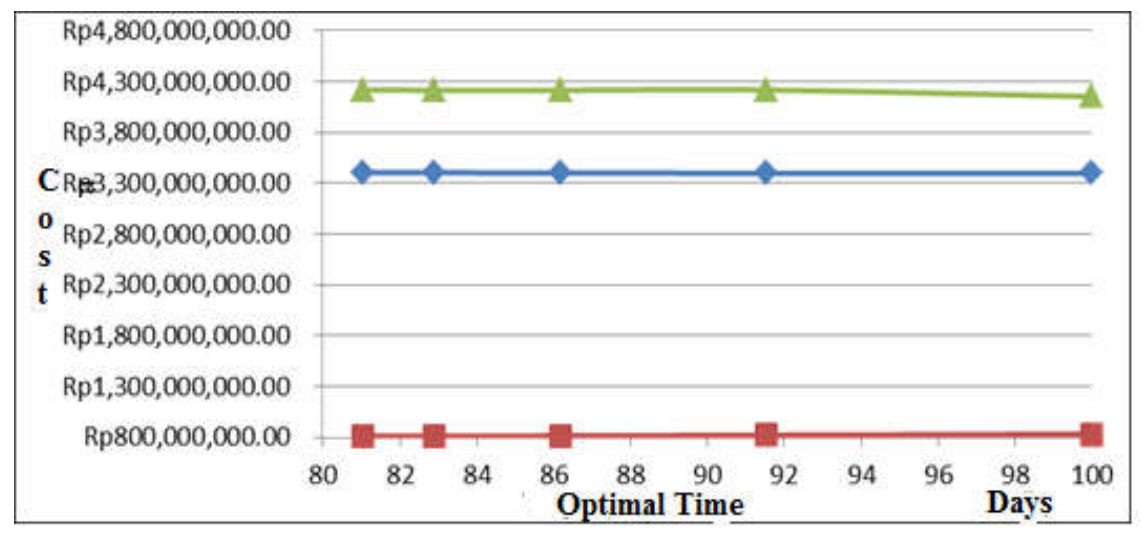

Figure 1 - Relationship between Time and Cost toward Project Total Cost 
From the table have some variation of the fastest time output with the addition of cost. From the series of new project completion time, an effective project completion time is chosen with the minimum project cost increment. The relation between time and cost on 2 hours overtime work can be seen in the Figure 1.

According to figure 1 , can obtained the most benefit alternative for finishing the project is 2 hours overtime work and also the most optimal phase. With this alternative, time for finishing the project experiencing 14 days acceleration as well as increasing cost of IDR $62.169,00$. This phenomenon indicating a TCTO method can causing many time can use as an overtime work however, also can increase the cost of project execution.

\section{DISCUSSION OF RESULTS}

The following table shows the results of the recapitulation of the two alternatives that have reached the optimal stage in terms of time and cost.

Table 3 - Recapitulation of Cost Additions

\begin{tabular}{|c|c|c|c|c|c|}
\hline No. & Overtime & Time & Acceleration & Total Cost & Added Cost \\
\hline 1 & Normal & 100 & 0 & IDR 4.152.507.000,00 & 0 \\
\hline 2 & 1 Hour & 91,54 & 8,46 & IDR 4.217.569.000,00 & IDR 65.062.000,00 \\
\hline 3 & 2 Hours & 86,19 & 13,81 & IDR 4.214.676.000,00 & IDR $62.169 .000,00$ \\
\hline 4 & 3 Hours & 82,87 & 17,13 & IDR 4.214.979.000,00 & IDR $62.472 .000,00$ \\
\hline 5 & 4 Hours & 81,05 & 18,95 & IDR 4.217.987.000,00 & IDR $65.480 .000,00$ \\
\hline
\end{tabular}

From table, the most profitable acceleration stage is by applying overtime work for six activities during 2 hours. The critical activities that get overtime work on 2-hour overtime are project nameboard, mini pile work, poor plate sand backfill, sills + door type P1, ceiling paint, and railing hollow stainless fence. Meanwhile, the acceleration cost is IDR 4.214.676.000,00 from the total normal cost of IDR 4.152.507.000,00.

In contrast, the total cost in table for normal hours is IDR 4.152.507.000,00, thus with the value, the selected value is the normal execution time. It is because the total cost at the normal time is the optimal time and the optimal cost which are obtained.

\section{CONCLUSION AND SUGGESTIONS}

The conclusions of this research are: 1) the optimal duration for completion of development project using TCTO method is 100 days with no additional hours, 2) the optimal cost needed is IDR 4.152.507.000,00,3) there are no additional cost from the initial contract value.

For construction employers, if the project can be ensured, there will be no retardation from the schedule specified on certain contractual agreements, but if an acceleration step wants to be done, then the implementation of TCTO can apply overtime work in one of the critical activities only. It is because in addition to completing the project faster but in terms of the cost of acceleration, it will require additional cost as well. In the event of a retardation by pursuing a predetermined schedule of contractual agreements, it is advisable to implement TCTO method for some critical activities. It is because in addition to completing the project on time or faster, the cost required for the acceleration can be clearly identified through TCTO method approach.

For further research, it is suggested that the research can be developed with other acceleration method. For further research, it is suggested that the research can be done with the recent SNI.

\section{REFERENCES}

1. Soeharto, I. (2001). Manajemen Proyek - Dari Konseptual Sampai Operasional, Jakarta. 
2. Popov, V., Juocevicius, V., Migilinskas, D., Ustinovichius, L., \& Mikalauskas, S. (2010). The use of a virtual building design and construction model for developing an effective project concept in 5D environment. Automation in construction, 19(3), 357-367.

3. Ghasemzadeh, F., \& Archer, N. P. (2000). Project portfolio selection through decision support. Decision support systems, 29(1), 73-88.

4. Breitman, R. L., \& Lucas, J. M. (1987). Planets: A modeling system for business planning. Interfaces, 17(1), 94-106.

5. Tompkins, J. A. (2010). Facilities planning. John Wiley \& Sons.

6. Pechmann, A., \& Schöler, I. (2011). Optimizing energy costs by intelligent production scheduling. Glocalized Solutions for Sustainability in Manufacturing, 293-298.

7. Austin, T., Larson, E., \& Ernst, D. (2002). SimpleScalar: An infrastructure for computer system modeling. Computer, 35(2), 59-67.

8. Elbeltagi, E. et al (2001). Schedule-dependent evolution of site layout planning. Construction Management \& Economics, 19(7), 689-697.

9. Pang, C., Dutta, P., \& Kezunovic, M. (2012). BEVs/PHEVs as dispersed energy storage for V2B uses in the smart grid. IEEE Transactions on Smart Grid, 3(1), 473-482.

10. Ko, C. H. (2009). RFID-based building maintenance system. Automation in Construction, 18(3), 275-284.

11. Zhang, H. (2006). Particle swarm optimization for resource-constrained project scheduling. International Journal of Project Management, 24(1), 83-92.

12. Yamin, R. A., \& Harmelink, D. J. (2001). Comparison of linear scheduling model (LSM) and critical path method (CPM). Journal of Construction Engineering and Management, 127(5), 374-381.

13. Rogalska, M. (2008). Time/cost optimization using hybrid evolutionary algorithm in construction project scheduling. Automation in Construction, 18(1), 24-31. 